\title{
INTERPRETASI VISUAL TIGA DIMENSI BUSANA MASYARAKAT JAWA AWAL ABAD KE- 19, BERDASAR ILUSTRASI J. B. WOLTERS DAN C. JETSES DALAM BUKU KITAB SI TALOE
}

\author{
${ }^{1}$ Edi Jatmiko, S.Sn, M.Sn., ${ }^{2}$ Krisna Tanaya Joestiono \\ 1,2 Program Studi Desain Komunikasi Visual ISI Yogyakarta \\ 12edijatmiko999@gmail.com, ${ }^{2}$ krisnatanayatok@gmail.com
}

\begin{abstract}
The book "Kitab Si Taloe" contains illustrations on textbooks for school children during the Dutch colonial era and the early independence of the Republic of Indonesia. The illustrations in these textbooks present pictures of events with the setting, architecture and clothing commonly used by generations at that time. This design focuses on discussing aspects of the clothing worn by the indigenous figures in the book. The Book of Si Taloe contains illustrations drawn by illustrators from both the Netherlands and the Natives. Of the many illustrators featured in this book, C. Jetses and J. B. Walters were chosen with consideration for their ability to present detailed illustrations, with neat lines and clear visual elements. It is intended that by taking clearer references, the results of the three-dimensional interpretation will be closer to accuracy and closer to the authenticity of the form of clothing used by Javanese people in the early 19th century. The aim is to identify and examine one of the important aspects in the journey and process of changes in Javanese civilization in terms of clothing.
\end{abstract}

Keywords: illustration, fashion, 19 th century, 3 d interpretation

\section{PENDAHULUAN}

Buku "Kitab Si Taloe" memuat ilustrasiilustrasi pada buku-buku pelajaran untuk anak sekolah di masa penjajahan kolonial Belanda dan awal-awal kemerdekaan Republik Indonesia. Ilustrasi-ilustrasi dalam buku-buku pelajaran tersebut menyajikan gambarangambaran peristiwa dengan setingan latar, aristektur maupun busana yang umum digunakan generasi pada waktu itu. Perancangan ini mengkhususkan membahas aspek busana yang dikenakan oleh para tokoh pribumi yang terdapat dalam buku tersebut. Kitab Si Taloe memuat ilustrasi yang digambar oleh ilustrator yang berasal dari Belanda maupun pribumi. Dari sekian illustrator yang ditampilkan dalam buku ini, C. Jetses dan J. B. Walters dipilih dengan pertimbangan kemampuan mereka dalam menyajikan ilustrasi secara detail, dengan guratan garis yang rapi dan elemen-elemen rupa yang jelas. Hal ini dimaksudkan dengan mengambil referensi yang lebih jelas maka hasil intepretasi tiga dimensinya akan lebih mendekati akurasi dan mendekati keaslian wujud busana yang digunakan masyarakat Jawa era abad ke- 19 awal. Adapun tujuannya untuk mengidentifikasi dan mengkaji salah satu aspek penting dalam perjalanan dan proses perubahan-perubahan peradaban orang-orang Jawa dalam hal berbusana.

Busana secara fungsi sebagai wujud budaya yang muncul karena unsur-unsur rohani dan jasmani dalam diri manusia, salah satunya yakni rasa malu atau minimal tidak nyaman jika ada bagian tubuh yang jasmani tidak tertutupi sehingga mempengaruhi 
aktivitas rohani, bagi pemilik tubuh maupun yang memandanginya. Mula-mula busana hanyalah penutup bagian tubuh dan pelindung dari obyek-obyek eksternal tubuh manusia yang mungkin mengancam ketahanan tubuh si pemakai busana tersebut. Tubuh manusia secara materi sangat rentan terhadap eksistensi alam di luar dirinya, baik pada kondisi alam yang normal maupun pada kondisi tertentu ketika alam memasuki kondisi yang ekstrim. Manusia membutuhkan pelapis dan pelindung yang mudah digunakan ketika bergerak dan berpindah-pindah.

Pada perkembangannya, ketika teknologi dari yang sederhana hingga muncul mesinmesin yang memproduksi bahan pembuat busana, hingga munculnya bentuk-bentuk desain baru yang terus berkembang, busana pada tahap tertentu dijadikan manusia sebagai penanda identitas. Identitas yang paling mendasar misal yang terkait gender dan usia, identitas yang terkait pada regional dan posisi maupun lokasi, hingga penanda kelas sosial.

Manusia yang hidup di pulau Jawa dan berbahasa Jawa berfalsafah "Ajine Rogo Songko Busono lan Ajine Diri Songko Lati”. Bahwasanya diri seseorang dinilai pada busana/pakaian dan kata-kata atau ucapan yang keluar dari mulutnya. Meski tidak ada kejelasan akurat mengenai falsafah ini munculnya kapan dan dari pihak berkuasa yakni keraton ke rakyat atau sebaliknya, atau muncul dalam masyarakat yang diajarkan para tokoh-tokoh cendikiawan pada masa lampau, namun falsafah ini tidak terbantahkan secara normatif. Jejak-jejak Ajine Rogo Songko Busono masih bisa kita temui terutama dalam salah satu unsur busana orang Jawa yakni corak batik. Referensi yang memungkinkan untuk diakses dalam rangka penelusuran perkembangan busana orang Jawa tentu bisa dimulai dari relief-relief candi Hindu-Budha, melompat ke artefak peninggalan kerajaan Majapahit hingga eksistensi keraton Mataram yang masih ada hingga hari ini. Dalam sejarah perkembangannya, orang Jawa kedatangan bangsa-bangsa lain dengan perkiraan abad ke4 oleh orang-orang yang berasal dari India dengan agama Hindu dan abad ke-7 oleh orang-orang Tiongkok, di saat yang sama orang-orang berbangsa Arab juga masuk ke tanah Jawa dan yang datang di era lebih akhir adalah bangsa Eropa yakni dalam catatan sejarah Belanda masuk ke Jawa sekitaran tahun 1600. Kedatangan bangsa-bangsa lain menimbulkan pengaruh akulturasi dan adaptasi masyarakat Jawa dalam hal berbusana, baik secara material, bentuk, corak, warna, dan cara penggunaan. Namun ada faktor lain yang cukup mempengaruhi eksistensi busana masyarakat Jawa yakni faktor kesejahteraan terutama pada era kolonialisme.

Penelitian ini mengkhususkan durasi yang terjadi pada paruh pertama abad ke-19 di pulau Jawa. Hal ini dilakukan karena rentang era tersebut ada upaya dokumentasi secara ilustrasi yang dilakukan pemerintah Belanda yang ditugaskan kepada J. B. Walters dan C. Jetses untuk menggambar kehidupan orangrang di Hindia Belanda. Beberapa karya Jetses masuk ke dalam buku-buku yang digunakan orang Indonesia maupun Belanda di Hindia Belanda. Adapun kumpulan dari buku-buku yang ilustrasinya digambar oleh J. B. Walters dan C. Jetses dikompositing dalam buku berjudul Judul: Kitab Si Taloe: Gambar Watjan Botjah 1909-1961 yang disusun oleh: Sindhunata \& Hermanu, diterbitkan Bentara Budaya pada tahun 2008 setebal 251 
halaman. Illustrator J. B. Walters dan C. Jetses dipilih karena pertimbangan kemampuan memvisualkan dalam hal kedetailan dan tingkat akurasi yang lebih mendekati kondisi nyatanya.

\section{LANDASAN TEORI}

\section{Interpretasi Visual}

Lo (1976) interpretasi citra menurut Vink dilakukan dalam enam tahap yaitu a. Deteksi; b. Pengenalan dan identifikasi; c. Analisis; d. Deduksi; e. Klasifikasi; f. Idealisasi. Deteksi adalah penyadapan data secara selektif atas obyek (tampak langsung) dan elemen (tak tampak langsung) dari citra. Obyek tersebut dikenali, diidentifikasi, dan diikuti oleh proses pemisahan dengan penarikan garis batas kelompok obyek atau elemen yang memiliki kesamaan wujud. Lalu dilakukan proses deduksi yang dilakukan berdasarkan asas konvergensi bukti untuk prediksi terjadinya hubungan tertentu. Konvergensi bukti merupakan penggunaan bukti-bukti yang masing-masing saling mengarah ke satu titik simpul. Klasifikasi dilakukan untuk menyusun obyek dan elemen ke dalam sistem yang teratur. Tahap terakhir yaitu idealisasi atau penggambaran hasil dari interpretasi tersebut.

Hasil interpretasi citra sangat tergantung atas penafsir citra beserta tingkat referensinya. Tingkat referensi ialah keluasan dan kedalaman pengetahuan penafsir citra. Ada tiga tingkat referensi yaitu umum, lokal, dan khusus. Tingkat referensi umum yaitu pengetahuan umum penafsir citra tentang gejala dan proses yang diinterpretasi. Tingkat referensi lokal ialah pengetahuan atau keakraban penafsir citra terhadap lingkungan setempat atau daerah yang diinterpretasi. Tingkat referensi khusus ialah pengetahuan yang mendalam tentang proses dan gejala yang diinterpretasi.
Dengan mendasarkan atas pendapat Vink maka Lo mengutarakan bahwa interpretasi citra dilakukan dengan tahap-tahap seperti dibawah ini:

a. Deteksi;

b. Merumuskan identitas obyek dan elemen berdasarkan karakteristik foto seperti ukuran, bentuk, bayangan, rona, tekstur, pola dan situs;

c. Mencari arti melalui proses analisis dan deduksi;

d. Klasifikasi melalui serangkian keputusan, evaluasi, dsb., berdasarkan kriteria yang ada;

e. Teorisasi: menyusun teori atau menggunakan teori yang ada pada disiplin yang bersangkutan.

Pada dasarnya interpretasi citra terdiri dari dua proses yaitu proses perumusan identitas obyek dan elemen yang dideteksi pada citra dan proses untuk menemukan artinya pentingnya obyek dan elemen tersebut. Karakteristik foto seperti ukuran, bentuk, bayangan digunakan untuk identifikasi obyek, sedang proses yang lebih rumit yaitu analisis dan deduksi digunakan untuk menemukan hubungan yang berarti dalam proses yang kedua. Hasilnya berupa sebuah klasifikasi dalam upaya menyajikan sejenis keteraturan dan kaitan antara informasi kualitatif yang diperoleh. Klasifikasi ini menuju ke arah teorisasi. Teorisasi ialah penyusunan teori berdasarkan penelitian yang bersangkutan atau penggunaan teori yang ada sebagai dasar analisis dan penarikan kesimpulan dalam penelitian. Dengan demikian maka interpretasi citra pada dasarnya berupa proses klasifikasi yang bertujuan untuk memasukkan gambaran 
pada citra ke dalam kelompok yang tepat sehingga diperoleh pola kelompok.

\section{Kitab Si Taloe}

Kitab Si Taloe merupakan buku terbitan Bentara Budaya, memuat berbagai ilustrasi dari buku-buku pelajaran sekolah dasar di setengah awal abad ke-19. Buku ini berisi sekian banyak ilustrasi yang menggambarkan kehidupan anak-anak maupun masyarakat di Jawa kala itu. Gambaran-gambaran yang memuat aktivitas-aktivitas, kejadian-kejadian sehari-hari, interaksi-interaksi masyarakat kala itu. Selain aktivitas ini berlatar belakang rumah-rumah dan bangunan-bangunan fisik yang umum dimiliki oleh masyarakat pada jaman tersebut. Penelitian ini menitikberatkan pada pakaian yang dikenakan oleh tokohtokoh yang terdapat dalam buku Kitab Si Taloe. Dalam buku tersebut juga dipaparkan para illustrator yang berasal dari negri Belanda yang cukup terkenal yakni De Bruin W.K, C. Jetses, J. Wolters Van Blom, Suzon Beynon, J. Lary, Sierk Scroder Carl, ELW, F. Bemmel, L.C. Bouwman, Tilly Dalton, Hein Kray, Van Ingen, Menno. Ada lagi ilustrator orang Indonesia asli. Mereka adalah: R. Katamsi, B. Margana, D.S. Tanto, Soelardi, Surya, Abdoel Salam, Kamil, Saoeti Karim, Sjoeaib Sastradiwirdja, Nyi Sri Murtana.

Buku Kitab si Taloe disusun oleh Sindhunata dan disunting oleh Hermanu awalnya berupa katalog pameran "gambar Watjan Botjah 1909-1961" di Bentara Budaya Yogyakarta, Januari 2008. Pameran ini menampilkan ilustrasi berupa gambar reproduksi yang tercantum dalam buku-buku pelajaran dari zaman kolonial. Kumpulan ilustrasi dalam "kitab si Taloe" Mijn Hollandsch Boek, Ons Eigen Boek, Rood Wit en Blouw, Nederlands Leesboek, Pien en Mien, Ot en Sien, Koos en Kees, Langs Bloemenpaden, Bij Bob in De Bergen, Javaansche Lees Methode, Nederlands Talboek, Voor Jong Indonesie.

Disamping itu masih ada lagi yaitu: Jalan ke Barat, Lajang Watjan Aksara Latijn, Ngrewangi Opo Ngrusuhi, Wulangan Nembang, Kembang Setaman, Siti Karo Slamet, Gagaran Moelang Ndonggen, Boekoe Peladjaran Bahasa Melajoe, Mardi Siwi Majalah, Matja Titi Basa Lan Tjarita, Wulang Matja, Radjabrana Kapendem, Boedi Pekerti, Boedi Lan Kantjane, Wulang Basa, Tiga Sekawan, Tjampoer Bawoer, Sinar, Tjahaja, Hemat Pangkal Kaya, Ontjen-Ontjen Anjar, Rumah dan Halaman, Selangkah Demi Selangkah, Pantjaran Bahagia, Kelap Kelip, Matahari Terbit, Langkah Baru, Kitab si Asa, Ajo Matja, Di Kampung, Bendera Berkibar, Mardi Lan Marjam, Arumania, Patjitan, Djawi, Sekar Mekar. Visual dari buku ini berupa gambar-gambar hitam putih dan beberapa berwarna dilengkapi dengan berbagai contoh cerita dari berbagai buku yang telah disebutkan di atas. Adapun pameran "gambar Watjan Botjah 1909-1961" ini menampilkan ilustrasi berupa gambar reproduksi yang tercantum dalam buku-buku pelajaran dari zaman kolonial.

\section{Permodelan 3D}

Dalam grafik komputer 3D, pemodelan 3D adalah proses mengembangkan representasi matematis dari setiap permukaan objek (baik benda mati atau hidup) dalam tiga dimensi melalui perangkat lunak khusus. Produk ini disebut model 3D. Seseorang yang bekerja dengan model 3D dapat disebut sebagai artis 3D. Ini dapat ditampilkan sebagai gambar dua 
dimensi melalui proses yang disebut rendering 3D atau digunakan dalam simulasi fenomena fisik komputer. Model ini juga dapat dibuat secara fisik menggunakan perangkat pencetakan 3D.

Pemodelan 3d merupakan bagian dari grafik computer 3D, merupakan proses pengembangan dari representasi matematis pada tiap permukaan obyek pada benda-benda mati maupun hidup. Hasil akhir dari pemodelan 3D ditampilkan dalam gambar dua dimensi melalui proses yang disebut rendering 3D atau digunakan dalam simulasi fenomena fisik computer. Model dapat dibuat secara otomatis atau manual menggunakan Perangkat lunak pemodelan 3D adalah kelas perangkat lunak komputer grafis 3D yang digunakan untuk menghasilkan model 3D. Program individual dari kelas ini disebut pemodelan aplikasi atau pemodel.

\section{Model simulasi pakaian 3D}

Pemodelan kain adalah istilah yang digunakan untuk mensimulasikan kain dalam program komputer, biasanya dalam konteks grafik komputer 3D. Pendekatan utama yang digunakan untuk ini dapat diklasifikasikan menjadi tiga jenis dasar: geometris, fisik, dan partikel/energi. Energi lentur menggambarkan kekakuan kain, energi trellising menggambarkan gesernya kain (distorsi dalam bidang kain), energi gravitasi didasarkan pada akselerasi karena gravitasi.

Pada perkembangan terknologi informasi dewasa ini muncul perangkat-perangkat lunak yang mampu mengakomodasi simulasi kain pada busana manusia atau kebutuhan lainnya. Pengembangan perangkat lunak simulasi kain diantaranya yakni Marvelous Designer, CLO3D dan Optitex, dapat digunakan oleh para desainer dan perancang busana maupun seniman untuk memodelkan pakaian 3D secara dinamis di computer. Kebutuhan simulasi kain umumnya digunakan untuk kebutuhan video game, film animasi 3D, visual effect pada film lifeaction dan juga digunakan untuk industri fashion. Berbagai kemudahan yang ditawarkan oleh pemodelan 3D yakni:

a. Fleksibilitas, kemampuan untuk mengubah sudut atau menghidupkan gambar dengan rendering perubahan yang lebih cepat.

b. Kemudahan rendering, perhitungan otomatis dan rendering efek fotorealistik daripada visualisasi atau estimasi mental.

Photorealism yang akurat, lebih sedikit kemungkinan kesalahan manusia dalam salah penempatan, berlebihan, atau lupa untuk memasukkan efek visual.

\section{METODE PENELITIAN}

Metode yang digunakan pada penelitian ini adalah metode kualitatif deskriptif, yakni pengamatan bentuk-bentuk busana yang dipakai oleh karakter-karakter/tokoh yang ada dalam buku Kitab Si Taloe. Adapun langkahlangkah yang dilakukan dalam penelitian ini yakni:

a. Pengumpulan data

Data didapat dengan cara melakukan studi pustaka, yaitu dengan menelusuri sumbersumber kepustakaan dengan buku-buku dan referensi yang berkaitan dengan tema penulisan ini. Data diperoleh dari berbagai buku dan berbagai situs internet. Data yang didapat terdiri dari dua kategori, yaitu data primer dan data sekunder. Data 
primer adalah data utama berupa data unsur-unsur nirmana dalam buku Kitab Si Taloe: Gambar Watjan Botjah 19091961 yang disusun oleh: Sindhunata \& Hermanu, diterbitkan Bentara Budaya pada tahun 2008. Sedangkan data sekunder yaitu data yang mendukung objek dan teori penelitian tersebut.

\section{b. Analisis data}

Data yang terkumpul kemudian dianalisa dengan menggunakan metode deskriptif kualitatif dengan mengidentifikasi bentukbentuk busana yakni berupa potonganpotongan maupun susunan-susunan busana baik untuk bawahan, atasan, pakaian dalam, penutup kepala, alas kaki, maupun asesoris lainnya. Identifikasi busana dalam aspek material yakni bahan baku, jenis jahitan, warna, serat dan tekstur dari kain yang digunakan, dan terakhir pada posisi penggunaan busana tersebut dan karakteristik kelenturan maupun tekukan kain.

c. Intepretasi ilustrasi kedalam pemodelan 3D Intepretasi dua dimensi kedalam tiga dimensi untuk mengakomodasi simulasi kain pada busana pokok maupun asesoris yang digunakan oleh karakter/tokoh dalam buku Kitab Si Taloe. Perangkat lunak simulasi kain yang digunakan yakni Marvelous Designer, CLO3D dan Optitex. Software ini umum diguanakan oleh para desainer dan perancang busana maupun seniman untuk memodelkan pakaian 3D secara dinamis di komputer. d. Memaparkan hasil akhir.

Memaparkan hasil penelitian dalam bentuk katalog galeri yang terdiri dari hasil render dua dimensi atas busanabusana hasil identifikasi dan intepretasi dari buku Kitab Si Taloe.

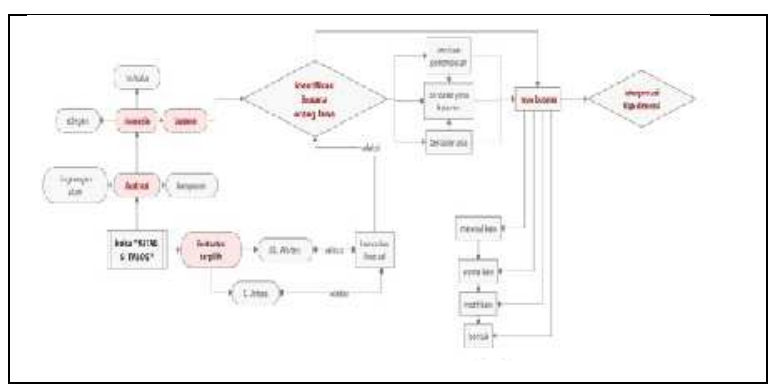

Gambar 1 Bagan Skematika Metode Perancangan Sumber: penulis

\section{HASIL YANG DICAPAI}

\section{Klasifikasi busana masyarakat pulau Jawa pada Abad ke-19 berdasar buku Kitab Si Taloe}

Kaslifikasi busana dalam buku ini diambil dari sekian banyak ilustrasi yang menggambarkan kehidupan anak-anak kecil maupun masyarakat di Jawa kala itu. Gambaran-gambaran yang memuat aktivitasaktivitas, kejadian-kejadian sehari-hari, interaksi-interaksi masyarakat kala itu. Selain aktivitas ini berlatar belakang rumah-rumah dan bangunan-bangunan fisik yang umum dimiliki oleh masyarakat pada jaman tersebut. Penelitian ini menitikberatkan pada pakaianpakaian yang dikenakan oleh tokoh-tokoh yang terdapat dalam buku tersebut. Dalam buku tersebut juga dipaparkan para illustrator yang berasal dari negeri Belanda yang cukup terkenal yakni C. Jetses dan J. B Wolters.

1. Mengidentifikasi bentuk pakaian; 
2. Penentuan klasifikasi berdasarkan jenis kelamin dan usia;

3. Melakukan analisis bentuk pakaian dan bagian-bagiannya;

4. Melakukan proses proyeksi piktorial, dengan dukungan data video dan fotografi serta paembahasan-pembahasan terkait bentuk pakaian orang Jawa masa kolonial;

5. Menentukan konfigurasi Jenis Entitas bagian-bagian pakaian;

6. Penempatan Entitas kain, bentuk, jenis kain, ketebalan;

7. Mensimulasikan Perilaku untuk Jenis Entitas (reaksi terhadap bentuk, grafitasi, tekanan dan masa kain);

8. Simulasi;

9. Rendering.

Ada beberapa tujuan yang ingin dihasilkan peneliti untuk mensimulasikan efek visual dari interpretasi visual tiga dimensi. Beberapa efek visual termasuk pada iluminasi kain yang dipilih, deformasi atau cara lipatan kain tertentu, dan tekstur visual kain. Kain visualisasi juga digunakan untuk animasi yakni sebagai landasan dalam menganimasikan kain dengan model realistis adalah salah satu asset yang digunakan dalam penguatan visual. Organisasi survei literatur ini adalah sebagai berikut. Untuk memahami pemodelan pakaian, penting untuk memahami terminologi mekanika tekstil. Banyaknya konsep yang digunakan untuk pemodelan kain virtual sangat didasarkan pada kemampuan menyusun parameter-parameter teknis dalam menu software pengembang simulasi pakaian. Salah satunya memahami bagaimana mekanika serat, mekanik benang yang kemudian mempengaruhi mekanika kain. Untuk alasan ini, bagian pertama akan menjadi ringkasan singkat tentang terminologi dan berbagai konsep teknik teknik tekstil. Bagian terakhir dari makalah ini akan membahas bagaimana simulasi pakaian dapat digunakan untuk menilik wujud asli yang mendekati dengan referensi aslinya.

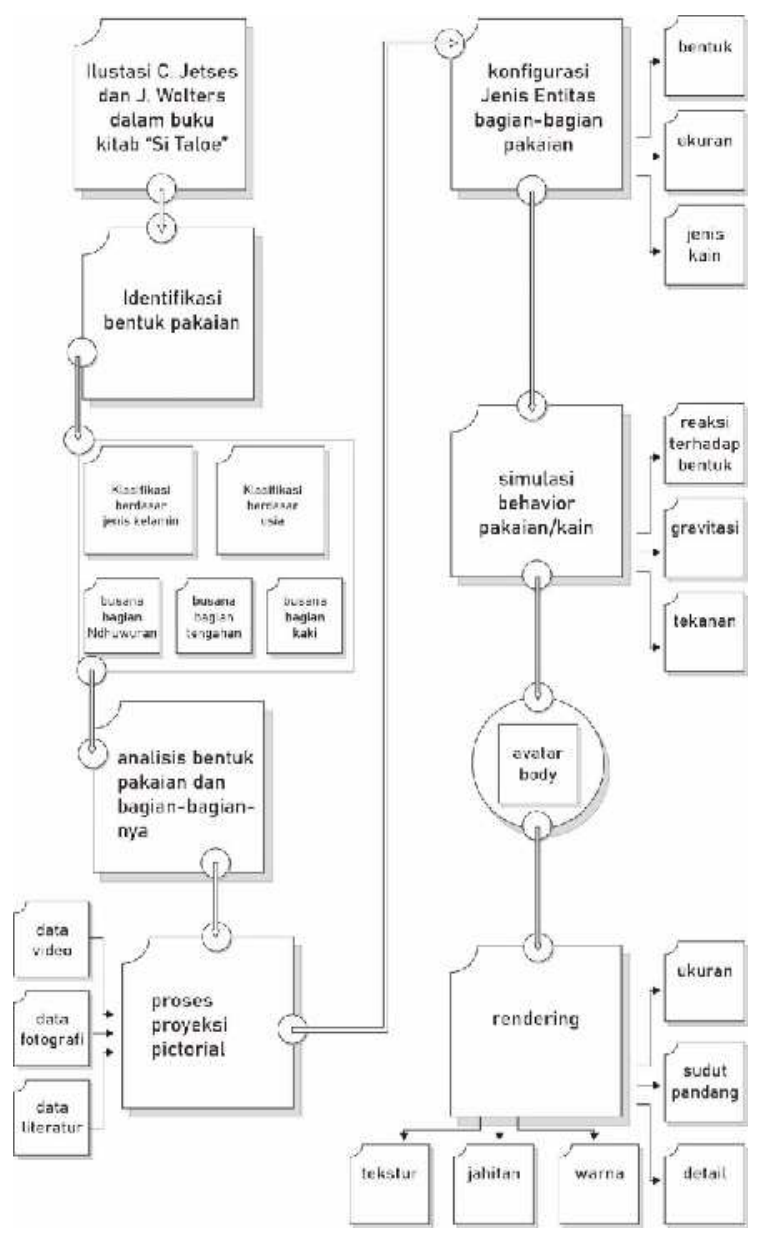

Gambar 2 Skematik teknologi virtual Hybrid Clothing simulation 


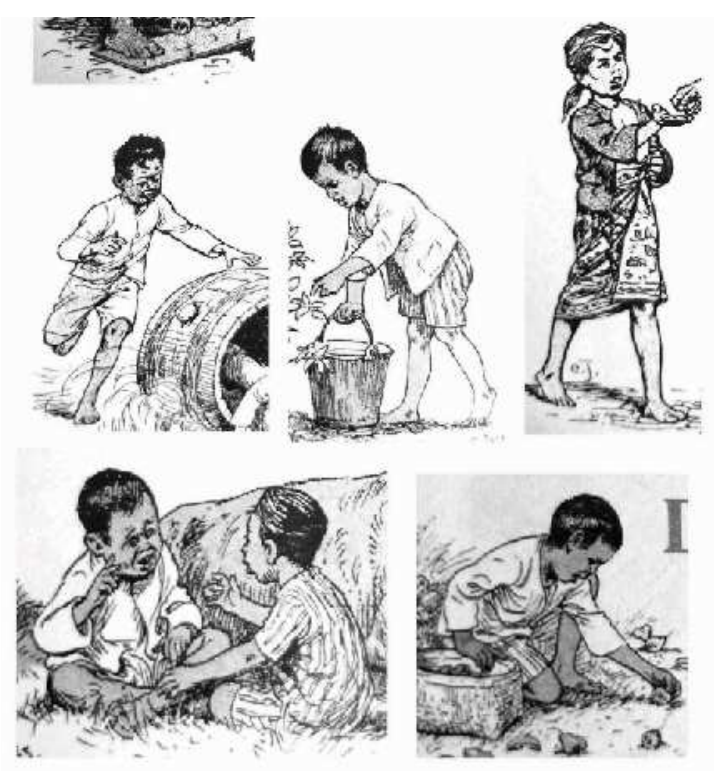

Gambar 3 Pengelompokan ilustrasi berdasar anak laki-laki
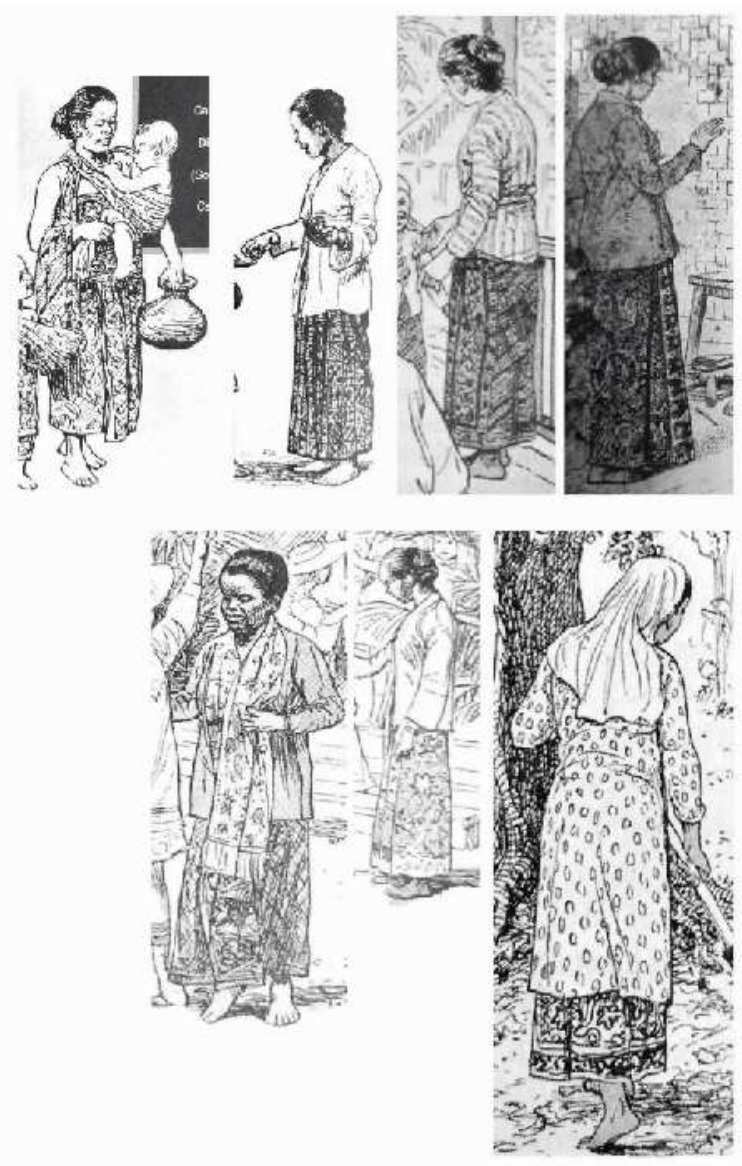

Gambar 4 Pengelompokan ilustrasi berdasar perempuan dewasa
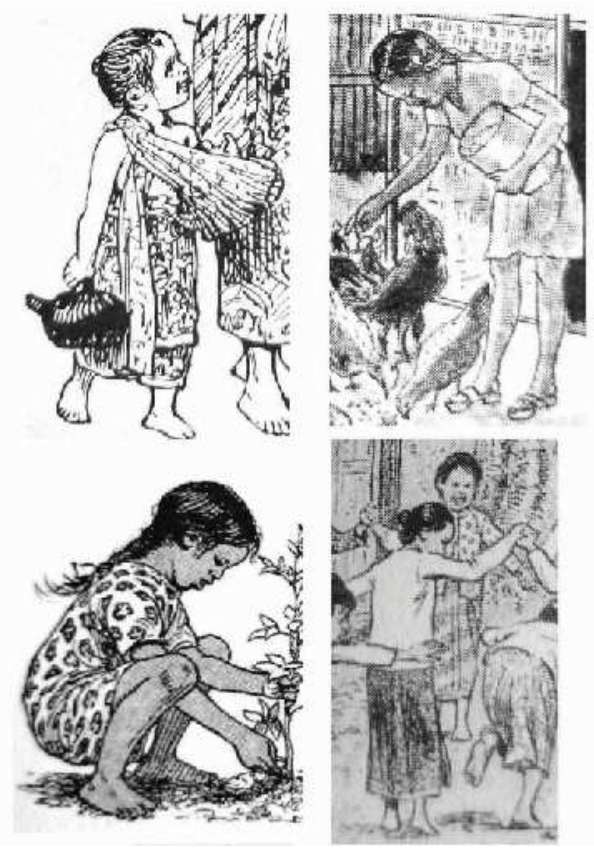

Gambar 5 Pengelompokan ilustrasi berdasar anak perempuan

Fokus interpretasi visual tiga dimensi adalah untuk mensimulasikan kain dan wujud busana yang umum digunakan orang Jawa era kolonial. Tujuan utama simulasi kain untuk aplikasi teknik meliputi bentuk dasar, ukuran ketebalan, behaviour kain, dan memastikan kedekatan visual dengan bentuk aslinya dalam kain yang dirancang dari versi ilustrasi ke versi tiga dimensi. Reaksi kain mencakup bagaimana kain menyentuh kulit (body) virtual dan seberapa banyak tekanan yang muncul antara tubuh dan kain. Pemodelan peta tekanan atau tekanan kontak antara kain dan kulit manusia diperlukan untuk mengetahui bagaimana wujud drapery kain Ketika bersentuhan dengan tubuh manusia. Sedangkan studi tentang begavior kain untuk menentukan analisis karakter perilaku simulatif kain ketika disetting sesuai parameter yang mendekati kehidupan nyata. Fokus utama lainnya untuk simulasi kain virtual adalah pemodelan dan animasi kain. 


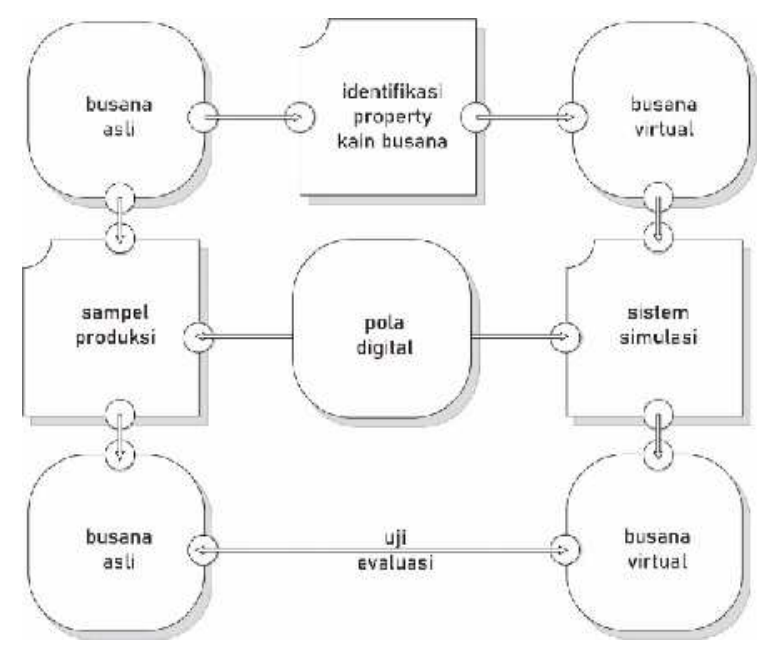

Gambar 6 Alur uji evaluasi virtual Hybrid Clothing simulation

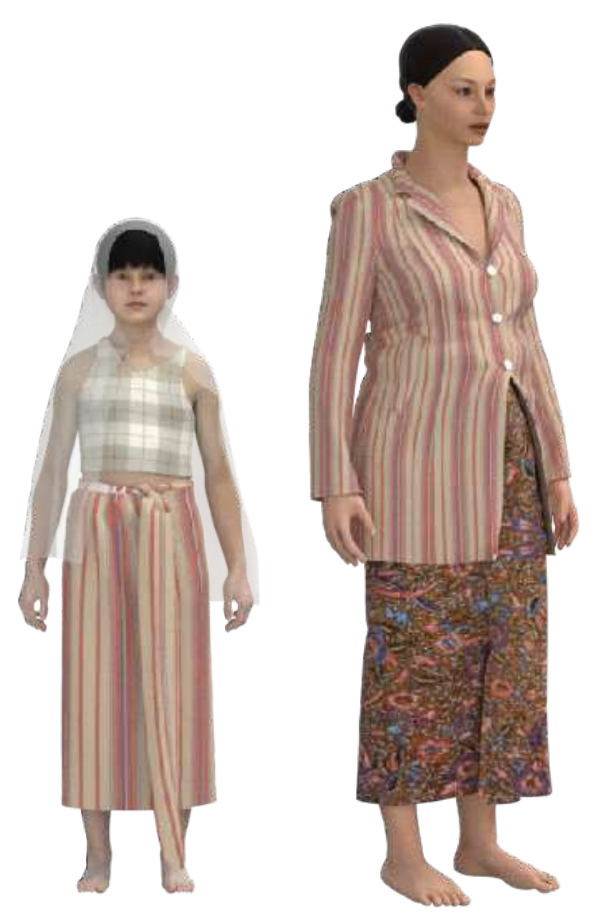

Gambar 7 Hasil intepretasi busana kelompok perempuan

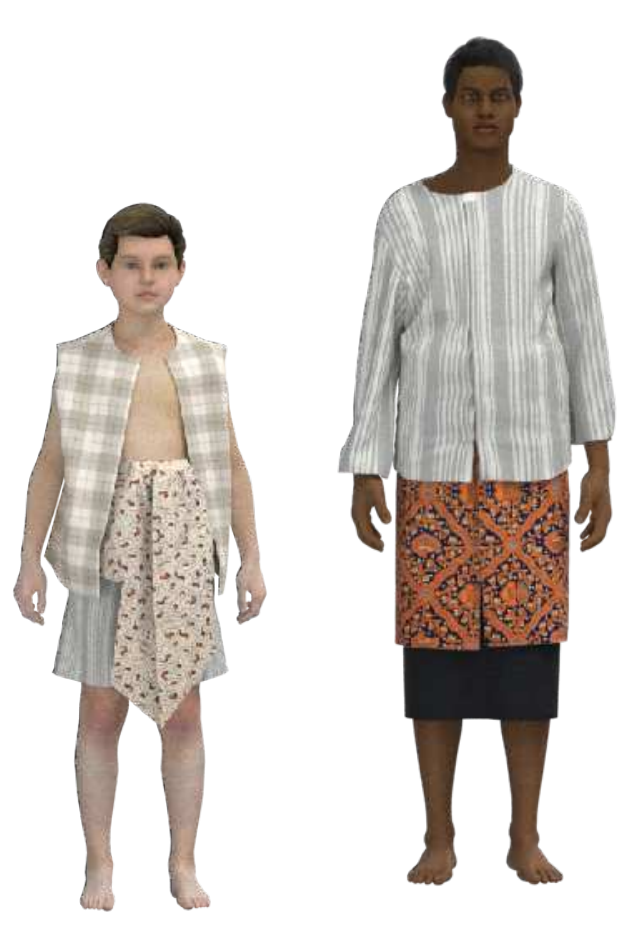

Gambar 8 Hasil intepretasi busana kelompok usia laki-laki dewasa

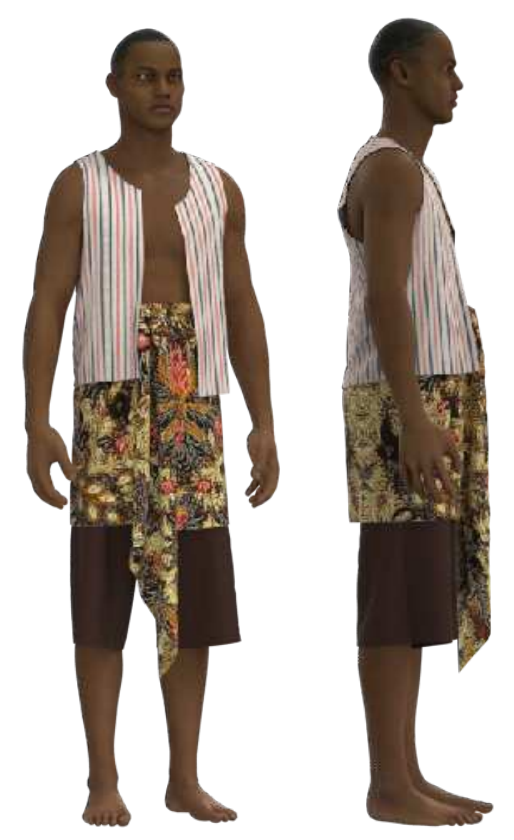

Gambar 9 Hasil intepretasi busana kelompok usia laki-laki dewasa 

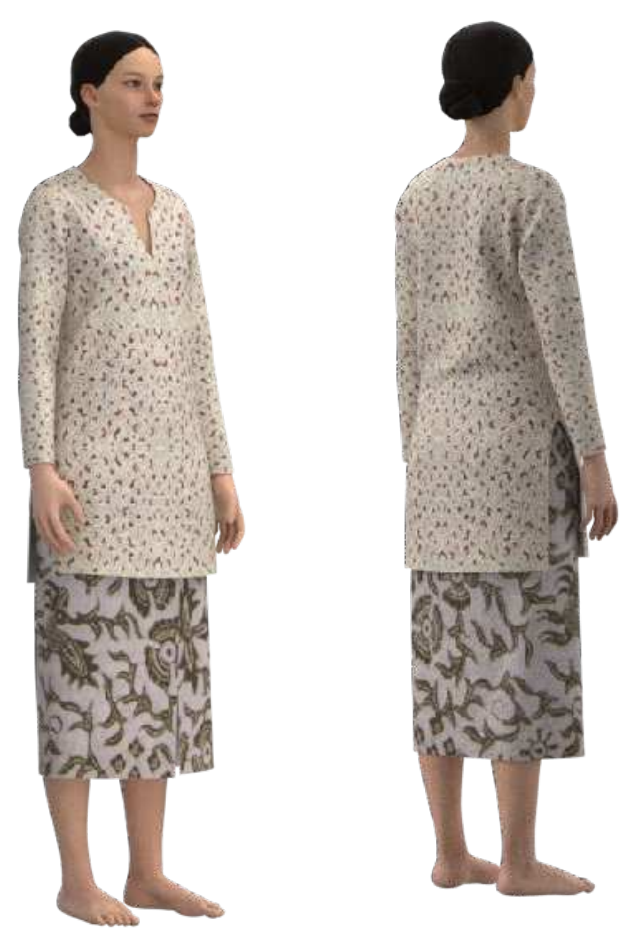

Gambar 10 Hasil intepretasi busana kelompok usia perempuan dewasa

\section{KESIMPULAN}

Penekanan penelitian ini yakni pada aspek visual antara dua format yang berbeda yakni ilustrasi yang dikerjakan secara manual dan tiga dimensi yang dikerjakan secara digital. Dua format visual ini tentunya memiliki karakterkarakter dan pola pengerjaan dan hasil output yang perbedaannya cukup signifikan meskipun menyorot dan mengangkat obyek yang sama yakni busana/pakaian. Ilustrasi yang dikerjakan secara manual dipengaruhi oleh karakter peralatan yang digunakan, peralatan ini berpengaruh pada tingkat kedekatan atau kemiripan dengan obyek sebenarnya. Ilustrasi yang menggunakan peralatan pena misalnya, hanya mampu menghadirkan wujud-wujud yang sifatnya hanya kesan dan bentuk umum, tidak sampai pada detailing dan keakuratan sesuai dengan wujud asli dari referensi yang diangkat. Sementara format tiga dimensi memiliki kapasitas untuk merancang dan menghadirkan wujud visual yang lebih mendekati obyek referensi.

Teknologi baik perangkat lunak maupun perangkat keras dewasa ini sudah mampu mengakomodasi kebutuhan untuk mensimulasikan karakter kain selayaknya obyek aslinya. Simulasi-simulasi tersebut mampu merespon hukum-hukum gravitasi, tekanan angin, massa benda dan penangkapan cahaya. Tak hanya itu, simulasi kain mampu menangkap sifat mekanik kain terputus-putus tidak homogen dan anisotropik. Struktur kain terdiri dari benang atau serat yang tumpang tindih yang ditenun pada sudut 90 derajat. Hal ini mengarah pada perilaku mekanis pakaian yang kompleks tidak sesederhana ilustrasi menggunakan tangan. Benang dirakit dari ribuan serat, kain dirakit dari ribuan untaian benang. Hal ini tentu tidak dapat dicapai dengan metode pengerjaan ilsutrasi secara manual. Tentu masing-masing format memiliki kelebihan kekurangan terkait tujuan perancangan yang digunakan. Karena keterbatasan wujud visual yang dihasilkan secara manual tangan maka untuk menginterpretasikan ke dalam wujud tiga dimensi diperlukan banyak sumber-sumber pendukung, misalnya dengan fotografi, footage video, dan pembahasan literatur. Ilustrasi umumnya hanya menghadirkan view dari satu sisi, sedangkan format tiga dimensi menghadirkan view yang bisa dirotasi 360 derajat. Maka dibutuhkan metode perancangan yang membutuhkan referensi tambahan dari sumber lain.

Dari keseluruhan jumlah ilustrasi dalam buku Kitab Si Taloe yakni 43 gambar gabungna 
dari illustrator C. Jetses dan J. Wolters, berupa gambar-gambar hitam putih dan beberapa berwarna dilengkapi dengan berbagai contoh cerita dari berbagai buku yang telah disebutkan diatas. Ilustrasi tersebut tersebar di beberapa halaman yang tidak berurutan. Sebelum diinterpretasikan kedalam visual tiga dimensi, perlu disusun berdasar tabel yakni dengan klasifikasi menjadi a) Kelompok berdasar jenis kelamin, b) Kelompok berdasar usia, c) Kelompok berdasar pekerjaan.

Perlunya penyusunan format dan struktur yang dapat dijadikan acuan dalam menginterpretasi wujud-wujud dua dimensional ke dalam format tiga dimensi terutama untuk konten non fiksi karena membutuhkan keakuratan dan kesesuaian yang mendekati dengan obyek referensi.

\section{DAFTAR PUSTAKA}

[1] Behrend, T.E. 1990. Katalog Induk Naskah-naskah Nusantara Jilid 1 Museum Sanabudaya. Jakarta: Djambatan.

[2] Condronegoro, Mari S. 1995. Busana Adat Keraton Yogyakarta. Yogyakarta: Yayasan Pustaka Nusatama.

[3] D. Baraff. Dynamic Simulation of Nonpenetrating Rigid Bodies. $\mathrm{PhD}$ thesis, Cornell University, May 1992.

[4] Humanika. 2004. Jurnal Gaya Berpakaian Perempuan Jawa pada Masa Kolonial. Jakarta: Perpustakaan UI.

[5] Kadir, Abdul, Adhi Susanto. 2013. Teori dan Aplikasi pengolahan Citra. Yogyakarta: Andi Offset

[6] Kees van Dijk, "Sarong, Jubbah, and Trousers. Appearance as a means of distriction and discrimination", dalam Jenk Schulte Nordholt (ed.), Outward Appearances. Dressing State and Society in Indonesia (Leiden: KITLV Press, 1977)

[7] Lo, C.P, 1995. Penginderan Jauh Terapan. UI- Press, Jakarta.
[8] Margana, S. Pujangga Jawa dan BayangBayang Kolonial, Yogyakarta: Pustaka Pelajar, 2004.

[9] Muslich KS. 2006. Moral Islam dalam serat Piwulang Pakubuwana IV. Yogyakarta: Global Pustaka Utama Yogyakarta.

[10] Ngatinah. 2008. Karaktekter Busana Kebesaran Raja Surakarta dan Yogyakarta Hadiningrat Periode 1755-2005. ITB J. Vis Art and Des, Vol. 2, No. 2, hlm.173-196.

[11] Poerwodarminto, WJS. 1939. Baoesastra Djawa. Batavia: J.B. Walters' UitgeversMaatschappij N.V. Raffles,

[12] Putra Darma. 2010. Pengolahan Citra Digital. Yogyakarta: Andi Offset

[13] Rohaeni, heni, Yadi Mulyadi. 2013. Menggambar Busana. Bandung: Yrama Widya

[14] Sindhunata \& Hermanu, 2008. Kitab Si Taloe: Gambar Watjan Botjah 1909-1961. Yogyakarta: Bentara Budaya

[15] Stockdale, J. Joseph. 2010. Eksotisme Jawa, Ragam Kehidupan dan Kebudayaan Masyarakat Jawa. Jakarta: Progresif Book.

[16] Taylor, Jean Gelman Costume and Gender in Colonial Java, 1800-1940", dalam Henk Schulte Nordholt (ed.) Outward Appearces. Dressing State Society in Indonesia (Leiden: KITLV Press, 1977)

[17] Tjahja Tribinuka. (2014). Rekonstruksi Arsitektur Kerajaan Majapahit dari Relief, Artefak dan Situs Bersejarah. TEMU ILMIAH IPLBI

\section{Data Internet:}

[1] http://monaliasakwati.blogspot.com/2011 /01/lonsep-kebudayaan.html http://prasetijo.wordpress.com/2008/04/0 1/konsep-kebudayaan-menurut geertz.html 